\title{
Domestic Violence and Patriarchy in Turkey
}

\author{
Şevket Ökten \\ Associate Professor. Harran University, Faculty of Arts and Sciences, \\ Department of Sociology, "Şanlıurfa" Turkey.
}

\begin{abstract}
Violence against women being a global epidemic that kills tortures and maims women physically and psychologically. The most common and widespread form of the violence is domestic violence. Violent behaviors such as beating, pushing, slapping or throwing things by family members; sexual, emotional, economic violence against women in the home, within the family or in a relationship is considered as domestic violence. Domestic violence is common place in Turkey though majority of women do not justify its occurrences as indicated by different nationwide studies conducted in Turkey. Instead nearly half of women who were subjected to violence remained isolation and overwhelming majority of victims avoided to get help from status apparatus. This study attempts to find out that why nearly half of women who are subjected to physical violence in Turkey did not share their experiences of violence to anyone before these studies. This study regards the patriarchal system and practices as the obstruction which deter overwhelming majority of women who are subjected to physical violence to express their suffering and seek help from state apparatus.
\end{abstract}

Keywords: Patriarchy; Gender-based violence; Domestic Violence, Turkey

\section{Introduction}

Violence against women, a global epidemic that kills tortures and maims women physically and psychologically. This most pervasive form violation of human rights include the denial of women equality, dignity, security, their feeling of selfworthiness, and their rights to enjoy fundamental freedoms (UNICEF, 2000). Violence against women is defined as "any act of gender-based violence that results in, or is likely to result in physical, sexual or psychological harm or suffering to women, including threats of such acts, coercion or arbitrary deprivation of liberty, whether occurring in public or private life" (United Nations, 1993).

Violence against women is a manifestation of historically unequal power relations between men and women leading to the domination of men over women and discrimination against women by men (The United Nations Declaration on the Elimination of Violence against Women, General Assembly Resolution, December 1993). Violence against women is present in every country, cutting across boundaries of culture, class, education, income, ethnicity and age. Though most societies proscribe gender-based violence, however, in reality, women face violence and their basic human rights are being violated either under the garb of cultural practices and norms, or through the misinterpretation of religious tenants.

The most common and widespread form of the violence is Domestic violence. Violent behaviors such as beating, pushing, slapping or throwing things by family members; sexual, emotional, economic violence against women in the home, within the family or in a relationship is considered as domestic violence (WHO, 2005). Domestic violence is defined by the UN as "a form of violence that occurs in private life between individuals who are generally connected by sexual intercourse or by blood relation". This definition of domestic violence referring to the gender based roots of violence, recognize that "violence against women is one of the crucial social mechanisms by which women are forced into a subordinate position compared with men." The definition of violence is broadened by including the physical and psychological harms done against women in both private and public life. Violence taking place within the home, is very often effectively condoned by the tacit silence and the passivity displayed by the state and the law-enforcing machinery (UNICEF, 2000). The family often being equated with sanctuary- a place where individuals seek love, safety, security, and shelter is also the place, shown by evidences, where severe form of violence is perpetrated against women and girls and imperil their lives (UNICEF, 2000). Today, for 
millions of women home is a locus of terror; however, unfortunately, in most countries, domestic violence is considered as a private family matter.

Domestic violence is common place in Turkey though majority of women do not justify its occurrences as indicated by different nationwide studies conducted in Turkey. Instead nearly half of women who were subjected to violence remained isolation and overwhelming majority of victims avoided to get help from status apparatus. This study attempts to find out that why nearly half of women who are subjected to physical violence in Turkey did not share their experiences of violence to anyone before these studies and what are the obstruction which deter overwhelming majority of women who are subjected to physical violence to seek help from state apparatus.

\section{Domestic Violence against Women World Wide}

Domestic violence being tragically pervasive takes place across education, class, income and ethnic boundaries. An analysis of 35 studies by world Bank reveals that all around the world one quarter to one half of all women have suffered physical violence by an intimate partner. A World Bank analysis of 35 recent studies from industrialized and developing countries shows that one quarter to one half of all women have suffered physical abuse by an intimate partner.

According to reports, in the United States, 28 percent of the women are subject to domestic abuse by their immediate partners at least once in their life time. More than half of the female population are beaten up by their husbands/partners in the developing countries are also reported. In India, Philippines, and Kenya this rate is nearly 50 percent (UNESCO, 2000).

\section{Table - Domestic Violence against Women. In Industrialized Countries:}

\begin{tabular}{|c|c|}
\hline Canada: & $\begin{array}{l}\text { In Canada, } 29 \% \text { of women (a nationally representative sample of } 12,300 \text { women) reported } \\
\text { being physically assaulted by a current or former partner since the age of } 16 .\end{array}$ \\
\hline Japan: & $\begin{array}{l}\text { In Japan, } 59 \% \text { of } 796 \text { women surveyed in } 1993 \text { reported being physically abused by their } \\
\text { partner. }\end{array}$ \\
\hline $\begin{array}{l}\text { New } \\
\text { Zealand: }\end{array}$ & $\begin{array}{l}\text { In New Zealand, } 20 \% \text { of } 314 \text { women surveyed reported being hit or physically abused by a } \\
\text { male partner. }\end{array}$ \\
\hline Switzerland: & $\begin{array}{l}\text { In Switzerland, } 20 \% \text { of } 1,500 \text { women reported being physically assaulted according to a } 1997 \\
\text { survey. }\end{array}$ \\
\hline $\begin{array}{l}\text { United } \\
\text { Kingdom: }\end{array}$ & $\begin{array}{l}\text { In United Kingdom, 25\% of women (a random sample of women from one district) had been } \\
\text { punched or slapped by a partner or ex-partner in their lifetime. }\end{array}$ \\
\hline $\begin{array}{l}\text { United } \\
\text { States: }\end{array}$ & $\begin{array}{l}\text { In United States, } 28 \% \text { of women (a nationally representative sample of women) reported at } \\
\text { least one episode of physical violence from their partner. }\end{array}$ \\
\hline \multicolumn{2}{|c|}{ In Asia and the Pacific Countries: } \\
\hline Cambodia: & $\begin{array}{l}\text { In Cambodia, } 16 \% \text { of women (a nationally representative sample of women) reported being } \\
\text { physically abused by a spouse; } 8 \% \text { report being injured. }\end{array}$ \\
\hline India: & $\begin{array}{l}\text { In India, Up to } 45 \% \text { of married men acknowledged physically abusing their wives, according to } \\
\text { a } 1996 \text { survey of 6,902 men in the state of Uttar Pradesh. }\end{array}$ \\
\hline Korea: & $\begin{array}{l}\text { In Korea, } 38 \% \text { of wives reported being physically abused by their spouse, based on a survey of } \\
\text { a random sample of women. }\end{array}$ \\
\hline Thailand: & $\begin{array}{l}\text { In Thailand, } 20 \% \text { of husbands (a representative sample of } 619 \text { husbands) acknowledged } \\
\text { physically abusing their wives at least once in their marriage. }\end{array}$ \\
\hline \multicolumn{2}{|c|}{ In Central and Eastern European/CIS/Baltic States: } \\
\hline Estonia: & $\begin{array}{l}\text { In Estonia, } 29 \% \text { of women aged } 18-24 \text { fear domestic violence, and the share rises with age, } \\
\text { affecting } 52 \% \text { of women } 65 \text { or older, according to a } 1994 \text { survey of } 2,315 \text { women. }\end{array}$ \\
\hline Poland: & $\begin{array}{l}\text { In Poland, } 60 \% \text { of divorced women surveyed in } 1993 \text { by the Centre for the Examination of } \\
\text { Public Opinion reported having been hit at least once by their ex-husbands; an additional } 25 \% \\
\text { reported repeated violence. }\end{array}$ \\
\hline $\begin{array}{l}\text { Russia (St. } \\
\text { Petersburg): }\end{array}$ & $\begin{array}{l}\text { In Russia, } 25 \% \text { of girls (and } 11 \% \text { of boys) reported unwanted sexual } \\
\text { contact, according to a survey of } 174 \text { boys and } 172 \text { girls in grade } 10 \\
\text { (aged } 14-17 \text { ). }\end{array}$ \\
\hline
\end{tabular}


Tajikistan: $\quad$ In Tajkistan, $23 \%$ of 550 women aged $18-40$ reported physical abuse, according to a survey.

\begin{tabular}{|c|c|}
\hline \multicolumn{2}{|c|}{ In Middle East and Africa: } \\
\hline Egypt: & $\begin{array}{l}\text { In Egypt, } 35 \% \text { of women (a nationally representative sample of women) reported being beaten } \\
\text { by their husband at some point in their marriage. }\end{array}$ \\
\hline Israel: & $\begin{array}{l}\text { In Israel, } 32 \% \text { of women reported at least one episode of physical abuse by their partner and } \\
30 \% \text { report sexual coercion by their husbands in the previous year, according to a } 1997 \text { survey } \\
\text { of } 1,826 \text { Arab women. }\end{array}$ \\
\hline Kenya: & $\begin{array}{l}\text { In Kenya } 42 \% \text { of } 612 \text { women surveyed in one district reported having been beaten by a partner; } \\
\text { of those } 58 \% \text { reported that they were beaten often or sometimes. }\end{array}$ \\
\hline Uganda: & $\begin{array}{l}\text { In Uganda, } 41 \% \text { of women reported being beaten or physically harmed by a partner; } 41 \% \text { of } \\
\text { men reported beating their partner (representative sample of women and their partners in two } \\
\text { districts). }\end{array}$ \\
\hline Zimbabwe: & $\begin{array}{l}\text { In Zimbabwe, } 32 \% \text { of } 966 \text { women in one province reported physical abuse by a family or } \\
\text { household member since the age of } 16 \text {, according to a } 1996 \text { survey. }\end{array}$ \\
\hline \multicolumn{2}{|c|}{ In Latin America and Caribbean: } \\
\hline Chile: & $\begin{array}{l}\text { In Chile, } 26 \% \text { of women (representative sample of women from Santiago) reported at least one } \\
\text { episode of violence by a partner, } 11 \% \text { reported at least one episode of severe violence and } \\
15 \% \text { of women reported at least one episode of less severe violence. }\end{array}$ \\
\hline Colombia: & $\begin{array}{l}\text { In Colombia, } 19 \% \text { of } 6,097 \text { women surveyed have been physically assaulted by their partner in } \\
\text { their lifetime. }\end{array}$ \\
\hline Mexico: & $\begin{array}{l}\text { In Mexico, } 30 \% \text { of } 650 \text { women surveyed in Guadalajara reported at least one episode of } \\
\text { physical violence by a partner; } 13 \% \text { reported physical violence within the previous year, } \\
\text { according to a } 1997 \text { report. }\end{array}$ \\
\hline Nicaragua: & $\begin{array}{l}\text { In Nicaragua, } 52 \% \text { of women (representative sample of women in León) reported being } \\
\text { physically abused by a partner at least once; } 27 \% \text { reported physical abuse in the previous year, } \\
\text { according to a } 1996 \text { report. }\end{array}$ \\
\hline
\end{tabular}

Adapted from "Violence Against Women," WHO, FRH/WHD/97.8, "Women in Transition," Regional Monitoring Report, UNICEF 1999, and a study by Domestic Violence Research Centre, Japan.)

In India, more than 5,000 women are killed each year, mostly in kitchen fires designed to look like accidents, because their in-laws consider their dowries inadequate. In some countries of the Middle East and Latin America, husbands are often exonerated from killing an unfaithful, disobedient or wilful wife on the grounds of 'honour'. Fear of reprisal, censorship of sexual issues, the shame and blame of those violated, unquestioning acceptance of tradition and the stranglehold of male dominion all play their part. Physical and emotional violence are widespread in Turkey. Even though IPV against women is publicly recognized by country, patriarchal family structure still affects women's lives (Guvenc et al, 2014).

\section{Domestic Violence against Women in Turkey}

Patriarchal norms still predominate in the Turkish society, particularly inside the family; having strong impact on relations between husbands and wives. This can be reflected in local popular sayings such as "After all, he's your husband; he can both love you and beat you" (Kocacık, et al. 2007). This type of saying causes and perpetuates the violence against women and perpetrators use this type of saying in the justification of their violence. As a result, there is no reduction in domestic violence even though women regard the violence against them unacceptable. Many study suggests the common prevalence of domestic violence in Turkey, however, many victims do not disclose the violence. Having got publically recognition from the state, patriarchal family structure still affects women's lives and violence against women in Turkey, is still regarded as a private matter.

In 1990s, the survey conducted by the Family Research Institution (as cited in Altinay and Arat, 2009 ) found that 30 percent of women stated that they are beaten up by their husbands and 34 percent husbands revealed that they perpetrated physical violence to their wives (Aile İçi Şiddetin Sebep ve Sonuçları, 1995, 136-137). Esmer in 1991 (as cited in Kocacik, et al., 2007) conducted interviews from 116 couples in Istanbul and found that more than 50 percent of husbands admitted that they beat up their wives. 
The National Research on Domestic Violence against Women in Turkey (2008) study was the first national study to provide official statistics on the prevalence and consequences of domestic violence in Turkey. This was also the most comprehensive study with its large sample size (12,795 women) from51 provinces and one of the biggest surveys in the world using face to face interviews (DGSW 2009). Overall, 39 percent of women reported having experienced physical partner violence at any time in their lives. In other words, 4 out of 10 women have been exposed to physical violence by their husbands or intimate partner(s). Although there is no significant variation between urban and rural areas nationwide, there is considerable variation between regions. The proportion of women experiencing physical violence varies between 25 and 53 among regions (DGSW 2009).

Altinay and Arat (2009) conducted a nationwide research and their findings showed that 35 percent of women for the turkey sample and 40 percent of women for the Eastern Turkey were subjected to physical violence (in the form of slapping, shoving or beating) at least once in their lives by their husbands. Thus, the figure of women subjected to violence has not changed in that duration.

Despite the fact that some initial survey finding suggested that women found violence against them justifiable, a nationwide research conducted by Altinay and Arat (2009) found that overwhelming majority of women who were subjected to violence, did not justify the physical violence. They also argued that though the overwhelming majority of respondents did not approve wife-beating and stated that wife-beating is unjustified, the occurrence of 35 percent physical violence indicate that women are not equipped to deal with physical violence perpetrated against them. The most pressing problem revealed by Altinay and Arat (2009) is the solitude of victims. They found that Nearly half of the women in Turkey who were subjected to violence had never shared their experiences of violence to anyone before this study and the percentage of solitude victims was 63 percent in East Turkey. Another noticeable thing is that the very low percentage of women seeks help from state apparatus and legal system. Just 3percent of women who were subjected to violence shared their experiences of violence to elected village official, police, gendarme, a lawyer, or public prosecutor (Altinay and Arat, 2009).

These above various studies conducted in different times indicate that there is no reduction in domestic violence against women in Turkey and many women silently endure the violence. Since this study attempts to find out that why nearly half of women who are subjected to physical violence in Turkey did not share their experiences of violence to anyone before these studies and what are the obstruction which deter overwhelming majority of women who are subjected to physical violence to seek help from state apparatus. To understand the domestic violence and silence of women on domestic violence, this study focuses on Patriarchy.

\section{Patriarchy in Turkey}

Patriarchal values are embedded in Turkish society which determines the subordinated position of women in Turkey. Patriarchy as a concept is defined in many ways in feminist literature. According to Lerner (1986) patriarchy is "the manifestation and institutionalization of male dominance over women and children in the family and the extension of male dominance over women in society in general". According to Lerner, male dominancy is systematic and institutionalized in the most important structures of society. Walby (1990) identifies patriarchy as system of social structure and practices wherein men dominate oppress and exploit women. Also, she identifies six structures of patriarchy which comprises of paid work, housework, sexuality culture, violence and the state and their relationships of these create different forms to capture the depth of women's subordination. Likewise, Hunnicutt (2009) states that there are patriarchal systems at the macro level (bureaucracies, government, law, market, religion) and patriarchal relations at the micro level (interactions, families, organizations, patterned behavior between intimates). The concept of patriarchy is mainly developed and used by feminism theories to explain the continuance male dominancy in modern societies. Patriarchal system necessitates the violence for the sake of its existence. Feminist analysis thus states that a patriarchal society is a direct cause of gender-based violence. Domestic violence against women can best be understood through the lenses of patriarchal system that subjugates women through socio-cultural values and norms of society which define and dictate the place and conduct of women. Sociologist explanation about the occurrence of domestic violence falls into the categories of both structural factors and cultural factors. Structurally, in the prevailing patriarchal system in Turkey weaken the status of women. Women are subordinate and subjugate gender in a patriarchal system and are more likely to suffer from gender-based violence including rape or domestic violence. Cultural explanations of sociologists uncover the myths associated with the intimate relationships. Many men continue to believe that their wives should obey them; any disobedience from their partner gives men "right" to hit them. Thus, this sort of ideology makes it much easier for men to hit their women. 
Patriarchal values are embedded in Turkish society which determines the subordinated position of women in Turkey. Patriarchal control over women is exercised through restrictive codes of behavior, gender segregation and the ideology which associates family honor to female virtue. The harmful customary practices against women in Turkey aim at preserving subjugation of women, defended and sanctified as cultural traditions and given morality overtones are amongst the most pervasive forces impacting upon the dignity of women. An irony with Turkish women is that if a victim woman speaks up about the violence either physical or sexual, she is seen with contempt and considered that she has lost the dignity of her and her family.

Domestic violence is occurring in Turkish society and generally women endured it silently. The instances of domestic violence are seldom reported as they are often treated as private matters. Men regard it their basic right to threaten or be physically violent to their wives to correct her behavior when women are seen as being disobedient. Domestic violence is a form of physical, sexual and psychological misuse of power exerted used against women. The silence of women on their own sufferings is due to the patriarchal system and practices which isolate them and impel them to suppress their own grievances.

\section{Conclusion and Recommendation}

Domestic violence is an expression and a symptom of a patriarchal social system. Feminist analysis states that a patriarchal society is a direct cause of domestic violence. Patriarchal values are embedded in Turkish society which determines the subordinated position of women in Turkey. The harmful customary practices in Turkey which aim at preserving subjugation of women, defended and sanctified as cultural traditions and given morality overtones are amongst the most pervasive forces impacting upon the dignity of women and causing domestic violence. In order to eliminate violence against women, in particular domestic violence, patriarchal system has to be eliminated which can be achieved by strengthening the social, political and economic position of women.

\section{References}

[1] Aile İçi Şiddetin Sebep ve Sonuçları. (1995). T.C. Başbakanlık Aile Araştırma Kurumu. Ankara: Bizim Büro.

[2] Altınay, G., and Arat, Y. (2009). Violence against women in Turkey: a nationwide survey. Published by Punto Publishing Solutions / Punto Baskı Çözümleri

[3] DGSW. (2009). Domestic violence against women in Turkey. Turkish Republic Prime Ministry Directorate General on the Status of Women. Published by Elma Teknik Basım matbaacılık.

[4] Esmer, Y. (1991). Algılama ve anlatımda es,ler arası farklılıklar (Perception and communication differences among couples). In N. Arat (Ed.), Kadın ve cinsellik (Women and sexuality). Istanbul: Say Yayınları.

[5] Guvenc, G., Akyuz, A., and Cesario, S.K. (2014). Intimate Partner Violence against Women in Turkey: A Synthesis of the Literature. Springer Science+Business Media New.

[6] Hunnicutt, G. (2009). Varieties of patriarchy and violence against women resurrecting "Patriarchy" as a theoretical tool. Violence Against Women, 15 (5), 553-573. Sage Publications.

[7] Kocacık, F., Kutlar, A., and Erselcan, F. (2007). Domestic violence against women: A field study in Turkey. The Social Science Journal 4 698-720.

[8] Lerner, G. (1986). The Creation of Patriarchy. New York: Oxford University Press.

[9] UNICEF. (1999). Conveying Concerns. Women report on gender based violence. UNICEF.

[10] UNICEF. (2000). Domestic violence against women and girls. Innocenti Digest. United Nations Children's Fund Innocenti Research Centre Florence, Italy.

[11] United Nations Declaration on the Elimination of Violence Against Women, General Assembly Resolution 48/104, Art 1.

[12] Walby, S. (1990) Theorizing Patriarchy, Oxford: Blackwell. 